\title{
Planning in the Era of Disruption: The Needs for Reflective and Responsive Planners, Challenges for Planning Education in Indonesia
}

One important lesson we have to note in this continuing pandemic Covid-19 is that we are now living in the era of 'disruption.' Although we enjoyed much progress and wealth in the past three decades of development and economic growth, we also witnessed turbulences and so many unpredicted socio, economic and environmental changes, including natural disasters on this small planet. The economic crisis happened in the late 1990s, the 2004 Tsunami in Aceh, earthquake in Central Java in 2006, and Mount Merapi Eruption in Yogyakarta in 2010, forest fires in Sumatera and Kalimantan in 2016-2017, earthquake in Lombok in 2018, and the earthquake and tsunami in Palu in 2019, brought so many losses, and other dynamic socio-economic changes and natural disasters in Indonesia. This series of events made us realize that we are facing a situation of uncertainties, complexities, turbulences - a disruption era. Such an era or situation may frustrate us, planners trained to predict, forecast, and prescribe the future. We are told that we, planners, are the only profession with the capacity, autonomy, and luxury to plan and determine the future. With such assumption, planners are considered master builders who have the authority to prepare 'the blueprint' for our cities and settlements in the future.

However, since the Covid-19 pandemic started in early 2020, which is still happening, we understand that we are already in the era and disruption. As explained by several authors, the era is characterized by VUCA: Volatile, Uncertainty, Complexity, and Ambiguity (Kasali, 2017). Yes, we have already experienced some of those four characteristics of the disruption era, but the Pandemic Covid-19 made us realize that such era is real and penetrates our regular way of life into something we never experienced before - including in planning and governing our cities and regions. In this era of very complex, dynamic, and uncertain socio, economic changes, I would argue that planners need to critically rethink their fundamental principles, assumptions, and therefore their works and practices.

The traditional practice of very deterministic, top-down, technocratic planning needs to be critically examined as such practices do not always work and benefit all societies. As Schon (1991) has argued, the planning model of 'technical rationality' has never been particularly good. He asks for 'critical-reflective practitioner/planner' - planners who have the capacity to reflect on action so as to engage in the process of continuous learning. In other words, Schon questions the current planning practices that are too deterministic and unable to respond to a very dynamic situation. He advocates the importance of reflecting

\begin{tabular}{|c|c|c|}
\hline $\begin{array}{l}\text { ARTICLE INFO } \\
\text { Received: December 29, } 2021 \\
\text { Received in revised form: December } \\
29,2021 \\
\text { Accepted: December 29,, } 2021 \\
\text { doi: } 10.46456 / \text { jisdep.v2i2.241 } \\
\text { (c) } 2021 \text { The Author }\end{array}$ & $\begin{array}{l}\text { JISDeP - The Journal of Indonesia } \\
\text { Sustainable Development Planning } \\
\text { Published by Centre for Planners' } \\
\text { Development, Education, and Training } \\
\text { (Pusbindiklatren), } \\
\text { Ministry of National Development } \\
\text { Planning/ National Development } \\
\text { Planning Agency (Bappenas), Republic } \\
\text { of Indonesia }\end{array}$ & $\begin{array}{l}\text { Address: Jalan Proklamasi 70, } \\
\text { Central Jakarta, Indonesia 10320 } \\
\text { Phone: }+622131928280 / 31928285 \\
\text { Fax: }+622131928281 \\
\text { E-mail: } \\
\text { journal.pusbindiklatren@bappenas.go.id } \\
\text { Supported by Indonesian Development Planners } \\
\text { Association (PPPI) }\end{array}$ \\
\hline
\end{tabular}


on what we are doing - the cultivation of the capacity to reflect IN action and ON action has become important. Drawing from the lessons from Pandemic Covid-19, we understand that there is a need to change the way planners think and act. It calls for planners to be more critical, reflective, and responsive, able to help communities knit their social and physical capitals - reflective planners who always learn and innovate in their everyday practices.

It is crucial for planning education to change or even transform their already conventional businesses in producing reflective planners. As argued by Caves and Wagner (2018), to be more practical, planning education should continually be open to and reflect the need of practitioners. Particularly in the era of very dynamic changes, continued inputs from practitioners will guarantee planning education to produce reflective planners and practitioners.

Such argument is also in line with Schon's (1991) views on higher education - how to produce "reflective practitioners" -who are always critical and continue to learn in their real practice after graduating from university. Universities, according to Schon (1991), are no longer the only source of learning. Universities are also not always developing sciences and knowledge as fast as the rapid changes in the real world. In this condition, the most appropriate educational approach is how to make sure students/graduates are not only equipped with the knowledge but also their ability to attain "long-life learning,' which is a concept to help students to be critical and to reflect on what they do in the real world. Reflective practitioners, including planners, continue to learn and be able to respond to various dynamics and unpredictable changes and developments.

Schon (1991) has reminded us that our society and its institutions are in continuous processes of transformation and uncertainty. Therefore, we must learn to understand, guide, influence, and manage these transformations and uncertainty. We must make the capacity to undertake them integral to ourselves and our institutions. In brief, he argues that we must become adept at learning. In addition, we must invent and develop institutions that are 'learning systems,' systems capable of bringing about their own continuing transformation.

Planning education in Indonesia had started in 1959 when the first planning school was established at Bandung Institute of Technology/ITB (Setiawan, 2018). After more than six decades since its foundation, planning education in Indonesia has grown more mature. Planning education in Indonesia is increasingly demanded to make a more tangible contribution to planning practice in the country. Planning education in Indonesia needs to change its approach, direction, and orientation. One of them is to step out of this traditional role of simply transferring knowledge and planning skills to students and inspiring and ensuring students adopt a variety of perspectives and more critical planning approaches.

In addition, planning education in Indonesia is not yet fully ready for a new era colored by the development of information and technology, disruption, and innovation. Despite these efforts, they have not been optimal and systematic in general. This is an important challenge of planning education in Indonesia in the future. Reforming the goals, curriculum, and learning methods more suitable to millennial students should also be the direction of planning education in Indonesia, particularly to respond to the era of disruption.

The experience during the Covid-19 pandemic since March 2020, when all planning educations in Indonesia had to transform to the online education model, can be the beginning of the transformation process and even an important step to bring planning education in Indonesia to the next stage - the era of digital society, disruption, and innovation. Planning has the spirit and essence of achieving a better future. Planning is a field of science and technology that contributes to providing prescriptions or solutions, both on current and future issues. Planning education should result in future-oriented planners and optimistic to provide solutions and realize a better future, even in the disruptions era and innovation.

Prof. Ir. Bakti Setiawan, MA, Ph.D.

(Editorial Board) 


\section{References:}

Caves, R., \& Wagner, F. (2018). Are planning programs delivering what planning students need? Perspectives on planning education from practitioners. In A. I. Frank \& C. Silver (Eds.), Urban planning education: Beginnings, global movement and future prospects (1st ed., pp. 323-336). Springer. https://doi.org/10.1007/978-3-319-55967-4_21

Kasali, R. (2017). Disruption. Gramedia Penerbit Utama.

Schon, D. A. (1991). The reflective practitioner: How professionals think in action. Ashgate Publishing.

Setiawan, B. (2018). The roles of planning education in the decentralization and democratization era: Lessons from Indonesia. In A. I. Frank \& C. Silver (Eds.), Urban planning education: Beginnings, global movement and future prospects (1st ed., pp. 219-231). Springer. https://doi.org/10.1007/978-3-31955967-4_15 